\title{
WHAT HAPPENS TO MS BABYLON IN ISAIAH 47, WHY, AND WHO SAYS SO? \\ John Goldingay
}

\section{Summary}

In Isaiah $47 \mathrm{Ms}$ Babylon is punished not for promiscuity or other sexual misdemeanour but for a failure in her womanhood which lies in a failure of womanly compassion. She is punished not by rape or sexual humiliation but by her reduction from a position of royal authority to one of domestic servanthood.

\section{Introduction}

Isaiah 47 has often been reckoned a passage in which a city is metaphorized into a woman punished for her promiscuity; its military assault and subjection are then being described in terms of a woman's sexual assault and rape. ${ }^{1}$ At the same time it comes within a section of the Hebrew Bible where a woman's voice has been discerned more explicitly than anywhere else in the Prophets. ${ }^{2}$ My aim here is to reconsider the chapter in the light of the apparent tension between these two views.

Ch. 47 is the only example in Isaiah $40-66$ of a prophecy against another nation; indeed 'in brief form, Isaiah 47 offers one of the most comprehensive statements of Israel's theology

\footnotetext{
${ }^{1}$ See e.g., P. Gordon and H.C. Washington, 'Rape as military metaphor in the Hebrew Bible' in A. Brenner (ed.), A Feminist Companion to the Latter Prophets (Sheffield: Sheffield Academic Press, 1995) 308-25 (316); and F.R. Magdalene, 'Ancient Near Eastern treaty curses and the ultimate texts of terror', pp. 326-52 in the same volume (331).

2See Bebb Wheeler Stone, 'Second Isaiah: Prophet to patriarchy', JSOT 56 (1992) 85-99.
} 
of the nations.'3 As such its functions might be expected to include those of indirectly warning the community not to be overly impressed by the enemy and of indirectly promising deliverance by portraying its oppressor's fall. 'Babylon presented itself as autonomous, invincible, and permanent' ( $c f$. vv. $7,8,10$ ), and Israel could easily accept this characterisation with its implications for Israel's own self-understanding and its understanding of God, 'a classic example of the phenomenon, noted by Marx, of the victim willingly participating in the ideology of the perpetrator'. The prophet's task is to enable people to see Babylon differently, and thus no longer to define their own position so hopelessly. ${ }^{4}$ The poem works by its ironic, even taunting bidding of a woman who had reckoned she would sit enthroned and secure for ever and could stand firm, not least on the basis of her resources of 'knowledge'. Her prestige, power, confidence, and faith will all turn out to be illusory. The taunt, overtly designed to demoralise the subject, is covertly designed to bolster the morale of poet and people.

Admittedly such statements are in part inferences based on the chapter's place in Isaiah $40-48$ as a whole and on the usual apparent functions of such oracles. If one were to put Isaiah 47 alongside the message of Jonah, one might ask whether it is a serious implicit invitation to Babylon to turn, like Jonah's implicit invitation to Nineveh-or alternatively whether Jonah confronts it with the necessity that the community should want Babylon to turn. Its nature as a prophecy addressed to another nation means that it is almost wholly about that other nation; Jacob-Israel and Sion-Jerusalem are unmentioned. This is one reason for the possibility of reading it in more than one way. Thus Bebb Wheeler Stone (90) argues that even Ms Babylon, 'a woman of the oppressor culture, is empathetically treated as woman and sister victim.' No doubt the poem can be read so, but it does not obviously invite such an understanding.

${ }^{3} \mathrm{~W}$. Brueggemann, 'At the mercy of Babylon' JBL 110 (1991) 3-22 (9) = Brueggemann, A Social Reading of the Old Testament (Minneapolis: Fortress, 1994) $111-33$ (118).

${ }^{4}$ Brueggemann art. cit. $4=$ op. cit. 113. 
Isaiah 47 takes up the custom of personifying a city or empire as a woman and specifically a daughter, a custom which also appears in the bare designation 'daughter Sion'. Oracles against other nations do sometimes portray this addressee in female terms (see ch. 23), but this is exceptional. They do also sometimes address the nation in the second person rather than speak about it in the third person (e.g., 14:29$31 ; 23: 1-12)$, but that is also exceptional. So the prophet chose to incorporate these motifs into the oracle against Babylon; it is not inherent in the form of such an oracle.

The figure perhaps has as one background the awareness that a society's young men are the people who go abroad seeking wealth and conquest; they 'represent the adventurous spirit of a society'. In contrast, daughters 'have been associated with stability, with the building up of society, with nurturing the community at its very heart and center.' Daughter Sion is thus Israel settled around the holy city which stands for 'civilization and culture... a stable lifestyle... permanent relationships' and either recipient of divine favour or, in ironic reversal, of wrath and punishment. 5 Another possible background is the divinisation of the city as a goddess, a patron god's consort. Israel demythologises this notion in portraying Sion-Jerusalem as Yahweh's wife and utilises it in order to portray the city's wrongdoing as unfaithfulness and its defeats as rape. ${ }^{6}$ Similarly, behind Isaiah 47 is then the notion of the goddess bewailing her city's fate. ${ }^{7}$

Lamentations 1 advertises many motifs which will follow in Isaiah 47: maiden daughter Sion has been widowed and her children taken, princess has become slave, the subject of mocking with none to help her; her stain was in her skirts but she did not call to mind her end. The metaphor is much

5So E.R. Follis, 'The holy city as daughter', in Follis (ed.), Directions in Biblical Hebrew Poetry (JSOTS 40; Sheffield: JSOT Press, 1987) 173-84 (17677)

6See A. Fitzgerald, 'The mythological background for the presentation of Jerusalem as a queen and false worship as adultery in the OT', CBQ 34 (1972) 403-16; 'BTWLT and BT as titles for capital cities', CBQ 37 (1975) 167-83.

${ }^{7}$ So F.W. Dobbs-Allsopp, Weep, O Daughter of Zion (Biblica et Orientalia 44; Rome: Pontifical Biblical Institute, 1993) 111. 
more common in Jeremiah and in Lamentations, but in Isaiah 47 it is explored with great rigour and consistency; there is no reference to Babylon's gates, walls, or sieges (or even its splendour), as if Babylon were a city. ${ }^{8}$ In Isaiah there is a complex interweaving of the images of the male figures of old and new David (chs. 7; 9; 11), king of Babylon (ch. 14), and Jacob-Israel as Yahweh's servant (chs. 41-49) with the female figures Sion-Jerusalem (esp. chs. 51-52, implicitly 54) and Babylon herself (ch. 47). Ch. 47 takes up chs. 13-14, but in doing so turns the focus from a male figure to a female one. This fact links with its talk not of military attack on a city but of the humiliation of a person. ${ }^{9}$ Bebb Wheeler Stone argues that Ms Babylon stands for the women of Babylon as Ms Sion stands for sinned-against Judean women (and Jacob-Israel for sinful Judean men), but this view is hard to sustain (e.g., in respect of 40:1-2 where Jerusalem has been paying the penalty for her own failings), and elsewhere she more helpfully comments (94) that in Isaiah 40-55 'sex becomes a trope, a rhetorical construct, not an attribute.'

One background to Isaiah $40-55$ as a whole is the humiliation of Jerusalem-Sion which passages such as Isaiah 3:16-26 announced and to whose actuality Lamentations witnesses. From the beginning chs. 40-55 had in mind Jerusalem-Sion's restoration. In the manner of these chapters, this theme's centrality is advertised precisely by the fact that it is initially briefly announced (see 40:2, 9) rather than immediately expounded at length. The lengthy development of the theme will come in chs. 49-52; 54;60-62. It is an exaggeration to describe ch. 47 as a pivot in chs. $40-55,10$ but the portrait of the humiliation of Babylon is part of the movement towards that full exposition. Sion has had her Cinderella

${ }^{8}$ See J.F.A. Sawyer, 'Daughter of Zion and servant of the Lord in Isaiah', JSOT 44 (1989) 89-107.

9So J. Vermeylen, 'L'unité du livre d'Isaïe', in Vermeylen (ed.), The Book of Isaiah (BETL 81; Leuven: Leuven UP, 1989) 11-53 (41).

${ }^{10}$ Against C. Franke, 'Reversals of fortune in the ancient Near East', in R.F. Melugin and M.A. Sweeney (eds.), Nerv Visions of Isaiah (JSOTS 214; Sheffield: Sheffield Academic Press, 1996) 104-23 (119). See also M.E. Biddle, 'Lady Zion's alter egos', pp. 124-39 in the same volume (see 12933). 
experience; now she is to change place with her sister.11 That exaltation presupposes this humiliation.

\section{From Throne to Servitude (vv. 1-4)}

V. 1a. Get down, sit in the dirt, maiden daughter Babylon. Sit on the ground without a throne, daughter Chaldea. The opening verb establishes the theme of the poem as a whole, a downward movement which turns Ms Babylon's position upside down and takes her from height to depth. The further requirement to 'sit' recalls the first verb in Lamentations: 'O how she sits alone, the city full of people.' We have noted how Lamentations 1 forms the background to much of the portrait which follows. The repetition of this imperious imperatival 'sit', using a verb which will reappear four more times (vv. 5, 8a, 8b, 14), also 'sets the tone for the entire poem'.12

Here the addressee is to sit in the dirt, on the ground. Is the dirt-ground literal and physical or metaphorical and metaphysical, and what is the significance of sitting there? The Akkadian and Ugaritic cognates of אר can mean the underworld, and there are passages where this meaning would

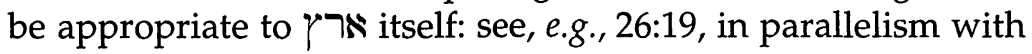
עפר. Here in v. 1 there is no explicit allusion to death; the primary reference is to a literal sitting in the dirt, on the ground. It will emerge in v. 2 that the addressee sits on the ground in order to do her work. Yet it will also emerge that some of her 'down-to-earth' experiences are described in such a way as to hint at their pointing to something else; and if she and the prophet's other hearers heard here overtones of reference to death and the underworld and found that these added to the sombreness of the command, they may not have missed the prophet's intention.

To be in the dirt is a sign of lowliness or ordinariness; to be put there is thus a sign of humiliation (2:9-22). But to sit

\footnotetext{
11See W. Grimm and K. Dittert, Deuterojesaja (Stuttgart: Calwer, 1990) 1:53; cf. C. Franke, 'The function of the satiric lament over Babylon in Second Isaiah', VT 41 (1991) 408-18.

${ }^{12}$ C. Franke, Isaiah 46, 47, and 48 (Winona Lake: Eisenbrauns, 1993) 147.
} 
on the ground is also a sign of grief $(3: 26 ; \mathrm{Jb}$. 2:13; La. 2:10). Here the contrast with $46: 13$ already points in the direction of humiliation, and the content of vv. 1-7 will confirm this, but issues of sympathy and grief will also be raised by vv. 6 and 9 , and the two experiences of humiliation and grief may both be involved as Ms Babylon finds herself sitting in the dirt (cf. 3:26 in its context; also 5:13-17; 14:3-21 for the collocation of death and humiliation).

For it is 'maiden daughter Babylon' who is addressed. Once Jeremiah bade Judah's king and queen. to 'sit' in subjection, adding that 'your beautiful crown has come down' (Je. 13:18). Here the suffixed noun 'beauty' and the two verbs recur as successive words in $46: 13 ; 47: 1$. What is then striking is the nature of the reuse. It would have.been natural to reverse the events of 587 by calling on the Babylonian king to get down and sit in the dust as beauty reverts to the Judean monarchy. Instead, consistently with the prophet's earlier democratisation of the servant image (e.g., 41:8-9), it is Sion and Israel who are to receive Yahweh's beauty (52:2 will be a significant instance with close verbal parallel to $47: 1$ ), and the object of the prophet's double bidding is Babylon itself (to remove the metaphor, as Targum does with its 'kingdom of the congregation of Babylon'; cf. v. 2 as a whole), or Babylon herself (to follow the prophet's trope).

Her double title 'maiden daughter' appears on eight occasions in the Hebrew Bible, most of them significant as literary and historical context for Isaiah 47. In Lamentations $1: 15 ; 2: 13$ it is applied to Judah and Sion. In Isaiah 37:22 (= $2 \mathrm{Ki}$. 19:21); 23:12 it is applied to Sion and Sidon. In Jeremiah 14:17; 46:11 it is applied to 'my people' and Egypt. Isaiah 47 now addresses a maiden daughter Babylon who is correlative at least to maiden daughter Sion/Judah. Getting down and sitting in the dirt has been Sion/Judah's experience at the hands of Babylon; it will now be Babylon's own, on the way to Sion/ Judah's being lifted from the dirt and restored to honour. To call someone either 'maiden' or 'daughter' ought to suggest respect, tenderness, honour, and concerned recognition of vulnerability; to call a city by these terms ought to suggest regard for its beauty and refinement. There is thus harshness, 
even oxymoron, in the juxtaposition of the two imperatives and the two nouns.

The word 'daughter' carries no implication that the woman is young, any more than are the 'daughters of Sion/my city' (e.g., 3:16, 17; La. 3:51) who are simply its women inhabitants, or any more than is Ruth in Ruth $2: 8 ; 3: 10,11$. If Ruth is there addressed in respectful but friendly fashion as a daughter (perhaps French mademoiselle comes nearer than any English expression), the same connotation may attach to the addressing of a city thus. When 'daughter' is prefixed by 'maiden', this connotation is reinforced. A בתולה is a young unmarried woman. It is doubtful whether the implication 'virgin' necessarily attaches to the word, but in any case it suggests not so much that the woman is inviolate, a characteristic not generally attaching to the cities to which the word is applied, but that she is in full flower of strength and beauty;13 בתולותים are paired with בחולות (young men in the prime of youth) in (e.g.) Lamentations $1: 18 ; 2: 21$. So 'maiden daughter Babylon' is a term of respect and affection which pictures a city as a personable and honourable woman. Yet each time the double title is used, there is thus some irony about it. The one addressed is Sion or a foreign people in their wickedness or calamity. It is such a person who is told to get down and sit in the dirt.

'Without a throne' turns Ms Babylon into a royal figure, or rather an ex-royal figure, whose sitting without a throne contrasts with Yahweh's sitting on a throne on high in 6:1, but compares with the king of Babylon's fruitless aspiration to set his throne on high in 14:13. 'From sitting upon the world throne Babylon comes down to sit in the dust.'14 On the basis of the place of the throne motif in ch. 14 and in an Ugaritic funerary liturgy, C. Franke suggests that this, too, suggests a note of mourning and not merely humiliation. ${ }^{15}$

13So C.C. Torrey, The Second Isaiah (New York/Edinburgh: Scribner's/T. \& T. Clark, 1928) 369.

14E.J. Young, The Book of Isaiah (Grand Rapids: Eerdmans, 1972) 232

${ }^{15^{\prime}}$ The function of the oracles against Babylon in Isaiah 14 and $47^{\prime}$, in E.H. Lovering (ed.), Society of Biblical Literature 1993 Seminar Papers (Atlanta: 
V. 1b. For you will not continue to have people call you sensitive and

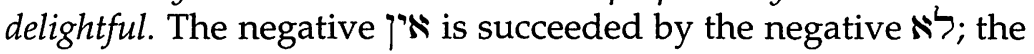
former will reappear in vv. 10,14, and 15, the latter in vv. 3, 5, $6,7,8,11$ (three times), and 14, giving the chapter its running negative tone: Babylon will/did not, not, not...

The two adjectives also come together in Deuteronomy $28: 54,56$, in the telling context of a warning about exile and its consequences for civilised people. They suggest the discriminating fastidiousness of someone who has been brought up in a context of good taste and privilege. They can have negative associations, of softness and 'not knowing what real life is like' or lack of seriousness, but what follows subverts any hearing of such associations here. The impact of the prophet's words will depend in part on the literal truth of the description of what Ms Babylon was (indeed in reality still is). She is all an Israelite might reasonably wish to be. She lives the life of a princess, the opposite of that of a slave. Her name for sensitivity and refinement is about to be taken away; there is no talk of any name to replace it, negative (contrast 34:12) or in due course positive (contrast, e.g., 1:26; 60:14; 61:3; 62:2, 4, 12):

The reader knows that Babylonia's army successfully laid siege to Jerusalem, creating the conditions that Deuteronomy envisioned (Lam 2:20; 4:10). But now, the tables are turned as tender, delicate Babylon goes down to the ground. ${ }^{16}$

V. 2a. Take millstones and grind meal. There is no new name, but there is a new experience which truly belies the old name. Grinding meal is the work of women, particularly women slaves: see Exodus 11:5 and the Instruction of Ptah-hotep 58-59 (ANET 412). ${ }^{17}$ But where there were no slaves it would be the work of ordinary people (the sound of the millstones is one of the archetypal features of the everyday life of an ordinary family: Je. 25:10), specifically of an ordinary woman. So from

Scholars Press, 1993) 250-59 (254-55); further 'Reversals of fortune in the ancient Near East', 110-13.

16K.P. Darr, Isaiah's Vision and the Family of God (Louisville: Westminster/ John Knox, 1994) 172.

${ }^{17} \mathrm{Cf}$. H.-J. Hermisson, Deuterojesaja (Neukirchen: Neukirchener, 1987-) 171. 
the privilege and refinement of the palace Ms Babylon has to move down to a woman's life of hard graft, perhaps that of a palace servant or slave, but quite likely simply that of an ordinary woman. She thus comes to share the life of her ordinary sisters from whose realities she is presently sheltered. She is subject to orders, obliged to give most of her time to the menial tasks which occupy most of the energy and hours of ordinary people, and forced to abandon the elegant style of the palace court for the stripped-for-work appearance of the domestic courtyard where the animals were kept, the corn ground and the food cooked.

V. 2b. Expose your hair. Uncover tresses. Expose legs. Cross streams. The general point of v. $2 \mathrm{~b}$ is clear, with its further cola bidding Ms Babylon to behave like any other ordinary woman, but the details are less so. The verb גלה (here piel) can mean 'strip off'-e.g., a veil ( $c f . \mathrm{LXX})$; a veil would normally be worn in public, especially by upper-class women and by married women generally, but not when one was doing hard domestic work, and not by slaves and prostitutes. This understanding fits the picture of 3:18-23, and the other uses of the noun in Song 4:1, 3; 6:7. But גלה more often means 'strip' (cf. Vulgate), and this understanding is required for the second occurrence of the verb, and for v. 3. D. Qimchi thus understands צמה to mean 'hair' which Ms Babylon is bidden to uncover (by removing the veil). ${ }^{18}$ This understanding is possible if less obvious for Song $4: 1,3 ; 6: 7$. The next verb, חשׁ, also generally means 'strip' and can apply to a garment or a part of the body. Its noun, שבל, occurs only here. A similar Arabic root suggests something flowing ( $c f . \mathrm{BDB})$; this again could be an item of clothing or could be a part of the body such as the hair ( $c f$. LXX). ${ }^{19}$ The suffix on the first noun can no doubt be assumed to extend its application at least to the next one.

18See his commentary incorporated in מקראות גדולות; also in A.J. Rosenberg, Isaiah (New York: Judaica, 1989) 2:381.

${ }^{19}$ A.F.L. Beeston ('Hebrew sibbolet and šobel', JSS 24 [1979] 175-77) suggests that it rather links with שבלת ('watercourse') and means a well, and that the verb here means 'draw water', hence 'draw (from) the well'. 
In the last pair of clauses the meaning of the individual words is clear; the problem lies with what the total picture refers to. In other contexts talk of baring legs could suggest rape, which fits with the language of v. 3; it is a standard feature of invasion. 20 Dobbs-Allsopp (112) interprets the removal of clothing in the light of the goddess's tearing of her garments in the ritual in which she bewails the fate of her city. In the specific present context, baring the legs more likely forms part of the picture of the inelegant behaviour that domestic activity forces on a woman. In the same way in other contexts talk of crossing rivers could suggest the long trudge of transportation, but in this context it more likely contributes further to the picture of the drudgery of domestic duty, particularly in Babylon with its many irrigation ditches. A woman has to hitch her skirts and expose herself in order to fulfil domestic duties such as washing clothes. ${ }^{21}$ At the same time the actual words 'cross' and 'rivers' have come together once before, at $43: 2$, where they seemed to be not a literal reference to the perils of a journey into or out of exile but a metaphor for the waters that might threaten the people on their corporate 'life journey'. That passage invites us to hear these overtones here, and v. $5 \mathrm{a}$ will confirm the point. Ms Babylon is going to have to pass through some deep water, as Ms Sion has.

The philological considerations leave $\mathrm{v}$. $2 \mathrm{~b}$ puzzling at several points. The choices we have made have the advantage of linking the cola into three coherent pairs.

V. 3a. Your nakedness is to be exposed, yes your disgrace is to be seen. Exposure of someone's nakedness (ערוה) is most frequently a term for sexual intercourse, especially as a euphemistic technical term in legal contexts (e.g., Lv. 18:6-19). As we have noted, in a passage which presupposes military defeat, reference to rape would not be surprising, nor reference to the sexual vulnerability of the female slave, but exposure of nakedness is not the obvious way to speak of either;22 Isaiah

${ }^{20}$ Cf. J.L. McKenzie, Second Isaiah (New York: Doubleday, 1968) 91.

${ }^{21}$ Cf. G.A.F. Knight, Deutero-Isaiah (Nashville: Abingdon, 1965) 156.

${ }^{22}$ Against Magdalene, 'Ancient Near Eastern treaty curses', 331. 
13:16 uses the verb סמס שמס, Jeremiah 13:22, Lamentations 5:11 ענה. When Lamentations 1:8 (significantly) and Ezekiel 16:37 speak of the exposure of Jerusalem's nakedness they mean just that-metaphorically, of course. Exposure is an act of humiliation (cf. similar phrases in Is. 3:17; Je. 13:26; Ho. 2:3, 10 $[5,12] ; \mathrm{Na}$. 3:5). Here the second colon seems to confirm that this is the phrase's significance here. ${ }^{23}$ In having to expose herself in order to fulfil her domestic duties, Ms Babylon will draw attention to the disgrace that is involved in the entire process of her humiliation. As happened at the end of v. 2, then, a description of a literal consequence of Ms Babylon's fall also hints at something more profound and all-embracing, the passage from honour to disgrace.

V. 3b. I will exact punishment, and no-one will intervene. ${ }^{24}$ Who speaks? While words such as those in vv. 1-3a could be uttered by Jacob-Israel or Sion-Jerusalem, there has been no indication that the speaker has changed since ch. 46 , and it is Yahweh who is the usual subject of the expressions 'punish/exact punishment' (לקח נקם, לקקם). Exacting punishment suggests the determined, insistent, and angry forcing of adequate retribution on someone for wrongdoing against people with whom the punisher is associated. It thus combines notions of

\footnotetext{
חרפה (disgrace) as a synonym for ערוה (TWAT on חרף ii, §II.2), but there is no other example of such usage. Further, parallelism makes one expect some development rather than simple repetition in the second colon, and ג ('yes', conventionally 'also') points to some addition even if it also functions to underline. This is especially so here where ג makes the line an unexpected 2-3, unusual especially in a quasi-lament where one expects two stresses in the second colon. It adds to the emphasis on the second colon and brings vv. 2-3a to a climax ( $c f$. Franke, Isaiah 46,47 , and 48,115). The word חרפה rather needs to be read against the background of its occurrences in 4:1; 51:7; 54:4; La. 5:1 (cf. the verb חרף in 37:4, 17, 23,24; also 65:7). 'Disgrace' is the opposite of 'honour'. Any humiliation is a disgrace (E. Kutsch, TWAT on ๆา ii, §II.2); hence the place here in vv. 1-3 of talk of disgrace.

24The second colon raises difficulties. MT reads ולא אפגע אדם which would presumably mean 'I will not meet a human being' or perhaps '... meet as a human being'; what sort of meeting would be determined by the context. I have followed Vulgate and Symmachus in reading a third person verb פיפני", perhaps altered through dittography.
} 
felt hostility, fairness, and identification. For Jacob-Israel to attribute punishing to Yahweh is to reassure itself that Yahweh has a commitment to right such as will generate action to restore the moral order of the universe by putting down oppressors and restoring Jacob-Israel itself. The notion is thus closely related to that of right (צדקה/צדק) and via it to the idea of Yahweh being restorer (מאל גושריע) (מושיע). What Yahweh is punishing is not stated; implicitly v. $6 \mathrm{~b}$ provides its rationale, but the effect here of stating no reasons, as well as underlining the mere fact, is to let the verb be an implicit synonym for 'deliver', as in 35:4. U.E. Simon comments that 'the corpus of Isaiah is particularly intent on retribution as an essential part of God's saving work'25_and vice versa, one might add. Yahweh's commitment to such punishment/ deliverance is the factor which lies behind the insistences of vv. $1-3 a$.

It is retribution for one and saving for another. For Ms Babylon there is nothing educative about her punishment, there are no exceptions (contrast Gn. 18-19), and there is no hope. But then the same was true of some prophetic statements about Ms Sion's punishment, as-we noted above-it was of Jonah's statements about Nineveh's. So there might be more here than meets the eye.

V.4. ...says our restorer, whose name is Yahweh almighty, holy one of Israel. A longer line brings the first section of the chapter to a powerful conclusion.26 When Ms Babylon loses her names, Yahweh does not.27 Reference to Yahweh's being Israel's 'restorer' (גאל) fits well in the context. A restorer's task could include the exacting of punishment as part of the task of reestablishing order (e.g., Nu. 35:9-28), and both נאם can and can

${ }^{25}$ A Theology of Salvation (London: SPCK 1961) 150.

${ }^{26} \mathrm{This}$ is true even of MT, whose v. 4 is an independent statement beginning with an extraposed phrase, 'Our restorer, his name is Yahweh almighty, holy one of Israel', or some such. It is apparently a word of response to the commitment in v. $3 \mathrm{~b}$. But the effect is choppy. I have followed LXX, which opens the verse $\varepsilon i \pi \varepsilon v$, suggesting Hebrew by homoioarkton after $\mathrm{Q}$.

${ }^{27}$ Cf. P.D. Miscall, Isaiah (Sheffield: Sheffield Academic Press, 1993) 114-15. 
be rendered 'avenge' in EVV. 'Restorer' points to the relationship behind insistence on recompense, so that $\mathrm{v} .4$ looks behind v. $3 \mathrm{~b}$ as v. $3 \mathrm{~b}$ looked behind vv. 1-3a. The plural suffix is unusual in Isaiah 40-55; Bebb Wheeler Stone (95) sees the voice here as an empathetic one which includes Babylonian women in the 'our', but the voice has not suggested such empathy and the hearers have hardly been given encouragement to hear the prophet that way. More likely the 'our' invites the prophet's own audience to apply the words to themselves individually, as at $42: 24$.

\section{From Power to Prison (vv. 5-7)}

V. 5. Sit in silence, enter into darkness, daughter Chaldea. For you will not continue to have people call you mistress of sovereign states. The chapter's second section resumes the starting-point of the first. It will take the argument on a stage, suggesting why Ms Babylon is to be subjected to the humiliation of vv. 1-3. The tendency there was to begin from literal descriptions of an ordinary woman's life which contrasted so much with that of a woman of the palace, and to hint at the way these concretise the humiliation, shame, and danger which Ms Babylon is about to experience. In vv. 5-7 the prophet again starts from the literal and concrete ('sit/go') but moves on very speedily to the more obviously abstract and metaphorical ('in silence/into darkness'). There is thus a parallelism between vv. 1 and 5 of the type that regularly obtains between two cola in a bicolon, combining repetition with variation and progression. ${ }^{28}$

In general terms the silence to which Ms Babylon is reduced is the kind to which human beings are brought by defeat, suffering, or oppression, or the prospect of these. Once again it is significant that silence is part of the suffering of Ms Sion after the fall of the city in Lamentations $2: 10 ; 3: 28$ and of that of Babylon in Jeremiah 50:30; 51:6. It suggests being numbed with terror and grief, dismayed, overwhelmed (cf. LXX

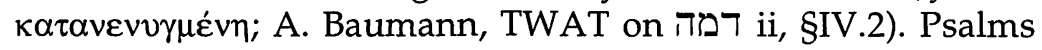
$31: 17$ [18]; $94: 17 ; 115: 17$ point to more specific connotations, for

${ }^{28}$ Franke, Isaiah 46, 47, and 48, 155. 
silence is a feature of the realm of death. ${ }^{29}$ Apparent allusions to mourning rites also often include reference to silencethough these may involve the use of דמם ii, 'mourn, moan', which would also be apposite here. Sitting in silence thus has parallel resonances to those of sitting in the dust/on the ground (v. 1).

'Darkness' has similar connotations as an Unheilsmetapher, an image which suggests the opposite to salvation. ${ }^{30}$ It can suggest evil, ignorance, disaster, death, curse, and punishment ( $c f$. H. Ringgren, TWAT on חשש, §IV). Isaiah 8:21-9:2 [1] warned of the darkness and gloom which would overtake Judah but then promised its replacement by light, and Isaiah of Babylon has reaffirmed that promise (e.g., 42:16). The prophet has also declared less specifically that people who 'sit in darkness' will be brought out from it, and has implied that this promise applies outside Israel as well as inside (see 42:6; $c f$. also La. 3:2). Here one who sits in light will be sent into darkness. The move from light to darkness which Ms Sion experienced is to happen to Ms Babylon as an aspect of the reversal which the chapter as a whole portrays. Any suggestion that she might in due course benefit from a restoration like Ms Sion's in line with 42:6 is left wholly implicit. Further, darkness, like silence, also suggests the realm of death (Pss. 88:12 [13]; 143:3; Jb. 3:5; 10:21-22)—as in Lamentations 3:6. The tomb itself, after all, is characterised by silence and by darkness.

The appellative 'daughter Chaldea' and the warning 'you will not continue to have people call you...' are repeated from v. 1 . In the new appellative in v. $5 b$ the word גברת corresponds to madame rather than mademoiselle; it denotes the female head of a household of some significance. Elsewhere in the Hebrew Bible the word is always set over against a word for 'servant'. גברת is a woman with power and responsibility in the home, a woman to be reckoned with. Madam Babylon is in that relationship to whole states. ${ }^{31}$ It is Babylon's vassal

${ }^{29}$ Indeed, LXX in the latter two passages (Pss. 93:17; 113:25) renders דומה

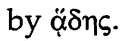

30 See Hermisson's comments on the passage

31The use of גבירה גברת ('queen') suggests that this is the metaphor the prophet uses-against BDB, which assumes that in Is. 47 
states that are the equivalent of the servant girls whom she is in a position to order about. Elsewhere the aspect of Babylon that strikes a prophet may be its splendour and pride (13:19) which made it admired throughout the world (Je. 51:41); here it is simply its power as sovereign over such an extensive empire. It is suggestive that these states are referred to as sovereign states (ממלכות). They are not merely עמים (peoples, ethnic groups) or גוים (foreign nations) but independent realms, which in theory controlled their own destinies, being ruled by a king or queen of their own. But a שפחה (female servant) was only rather nominally a free person rather than a slave, and these were only so-called sovereign states, because like her they were ruled by a גברת, with whom real power lay.

Who receives the sovereign power taken from Ms Babylon is here unstated. Passages such as 45:1-3; 46:10-11 might suggest it is Cyrus, but passages such as 45:4, 14 make clear that he is merely a means to an end and hint that the sovereign power might be on its way elsewhere (cf. 49:22-23; 55:5). 32 Here the focus lies on Babylon's deprivation rather than anyone else's gain, and even there the prophet does not overtly speak in terms of a mere transfer of Ms Babylon's power to Ms Sion.

V. 6a. I was angry with my people. I profaned my heritage. So I gave them into your power. It is no doubt implicit throughout that the punishment of Madam Babylon relates to her treatment of Yahweh's people, but only here is the point explicit, ${ }^{33}$ and it is made in such a way as to risk death by qualification. She is not punished for the mere fact of the invasion of Judah and the destruction of city and temple, as might be implied in Jeremiah

alone גברת means queen; HAL and DCH treat the two forms as forms of the same word. While morphologically גברת might simply be a construct

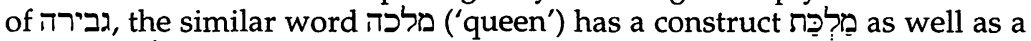

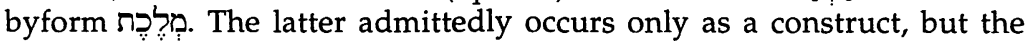
word for 'wall' occurs in the absolute as both גדרת and So there are parallels to support the possibility that גבר גבר might be a byform of גבירה which could occur both as a absolute and as a construct; the latter makes sense here, the former in v. 7.

32See Hermisson's comments on the passage.

${ }^{33}$ Cf. P. Volz, Jesaia: zweite Halfte (Leipzig: Deichert, 1932) 83. 
$50: 28 ; 51: 11,36$. One reason is that it was Yahweh who did it, anyway. ${ }^{34}$ Lamentations $2: 2 ; 5: 22$ have already described the fall of Jerusalem as happening because Yahweh was angry and have seen it as Yahweh's act of profaning ( $c f .42: 25 ; 43: 28)$ which is paradoxically the act of the holy one (v. 4), a response to Jacob-Israel's self-profanation. In the parallelism of the first line, as anger leads into profaning so its object changes from 'my people' to 'my possession' (נחלה; cf. Je. 12:7-9). The appropriate attitude to take to one's נחלה is modelled by Naboth, who scorns the notion of surrendering it as if any piece of property would do (1 Ki. 21:3). That was the stance Yahweh had once taken to Israel, but treating it as special, expecting it to be kept distinct from other peoples, and protecting it to that end, had been replaced by treating it as ordinary, open to the same treatment as other peoples.

So Yahweh's people could be surrendered to Madam Babylon just like any other people ( $c f$. Je. $21: 7 ; 27: 6)$. The point is the shocking obverse to the shocking Amos 9:7b. When Yahweh was involved in war, that was supposed to involve people being given into Israel's power (e.g., Nu. 21:34; Jos. 8:12). This is a perversion of that notion (Grimm/Dittert 2:289).

The lines separating God's treatment of his people and of Babylon are not hard and fast; indeed, the lines separating the brutal punishers-God, Assyria, Babylon, Media-are not hard and fast. ${ }^{35}$

V. 6b. You did not show them compassion. On an elder you weighted your yoke heavily. Verse $6 \mathrm{~b}$ follows $\mathrm{v}$. $6 \mathrm{a}$ without any grammatical link-no 'but' or 'and' or 'for'. All we get is mute parataxis. ${ }^{36}$ The hearer has to infer the links. The standard critique of a foreign power which appears in 10:5-19 is that a power which was supposed to be an agent of Yahweh's judgment behaved in a way which went beyond Yahweh's intent and/or acted to further its own selfish ends, so that an

${ }^{34} \mathrm{Cf}$. C. Westermann, Isaiah 40-66 (ET; London/Philadelphia: SCM/ Westminster, 1969) 191.

${ }^{35}$ Miscall, Isaiah, 115.

36Brueggemann, art. cit. $9=$ op. cit. 19. 
act of judgment on this agent rightly follows the use of the agent to fulfil the divine purpose. Madam Babylon is not at fault for the mere fact of having conquered Sion but for failing to take for granted that judgment is to be exercised in a way which respects limits and exercises restraint. But the critique differs from that of the king of Assyria in 10:5-19.

It begins with an indictment concerning 'compassion' (רהמים), a word which comes elsewhere in Isaiah 40-55 only at 54:7 (also 63:7, 15; not at all in 1-39), more rarely than one might have expected given the encouraging purpose of the chapters. ${ }^{37}$ The earlier chapters establish that Yahweh once intended no compassion for Israel at the hand of the Assyrians (9:17 [16]; cf. 27:11), then none for Babylon at the hand of the Medes (13:18), then renewed compassion for Jacob-Israel in restoring the people from exile $(14: 1 ; c f .30: 18)$. So Babylon's treatment of Yahweh's people fits with Yahweh's own policy-as v. 6a has itself made clear-but this has already been announced as due to be reversed. The specific content and background of רחמים has hardly been explicit there. The word is the plural of the word for 'womb' (cf. 46:3 where it is followed by reference to old age as here) ${ }^{38}$ and might be expected to suggest the deep identification that a mother feels with and for her children as the fruit of her womb. One would have to allow for the possibility that the word had escaped such a background; but the pattern of use in Isaiah 40-55, at least, suggests that this is not so, for the feelings, pains, and yearnings of Sion as wife and mother are an explicit concern in chs. 49 and 54 where the occurrences of verb and noun cluster, and it is telling that it is Babylon personified as a woman whom the (femalely-inclined) voice of the prophet indicts by using this word. This distinguishes the indictment from that offered regarding Assyria represented by its male monarch.

Here in ch. 47 the pain of Ms Sion lies in the near background, as Yahweh speaks on her behalf to Ms Babylon/ Madam Babylon, and what Yahweh accuses her of is a lack of

37The verb רחם (piel) comes in 49:10, 13, 15; 54:8, 10; 55:7 (also 9:17 [16]; $13: 18 ; 14: 1 ; 27: 11 ; 30: 18 ; 60: 10)$.

${ }^{38}$ Cf. W.A.M. Beuken, Jesaja, IIa (Nijkerk: Callenbach, 1979) 271. 
womanly feelings. This is the prophet's first critique. It is as a woman that Babylon has failed. As a woman she ought to have recognised that power politics are to be exercised in a way which remembers compassion. Even being the means of expressing Yahweh's anger does not exclude compassion (cf. 14:1), and a woman's human instincts might have been expected to give her that insight into the nature of God, even when God speaks in macho terms about trying to resist the instinct to compassion ( $c f$. Ho. 11). When this fails, Yahweh must intervene in politics with compassion talk and action. ${ }^{39}$

The 'elder' whom Madam Babylon oppressed might be a collective term for the older people in the community, or might be its senior leaders, or might be the community itself. But preoccupation with the reference of the term misses part of the point. It is the meaning and connotation of 'elder' rather than its reference which needs noting. A young woman, a daughter, a woman of the house might to be expected to care about the fate of an old person as she ought to have compassion for the fruit of her womb. It is this further indictment of her as a human being that is most important in the allusion to the elder. 40

V. 7a. You said, 'I will be here for ever, mistress in perpetuity'. 41The prophet's first and distinctive critique related to compassion and heartlessness. The second corresponds more closely that of ch. 10 and especially chs. 13-14 (see 14:13-14; also Ezk. 28 and later Rev. 18:7). It relates to arrogant self-confidence and selfassertiveness expressed in the royal ' $I$ '. Madam Babylon thought she was the climactic act of the play; she refused to recognise that she was part of a larger story and that her scene would end (cf. Miscall 115). She says אהיה ('I will be [here]'),

${ }^{39}$ See Brueggemann art. cit. $8-17=$ op. cit. 117-28.

${ }^{40}$ Likewise whatever the referent of the word, the 'yoke' is an image for the affliction and suffering built into defeat and exile ( $c f .42: 22)$; it need not suggest that the 'elder' was subject to forced labour. The image parallels that of compassion in that Babylon's imposition of a yoke (even an iron one) was God-directed (Je. 27-28; cf. Dt. 28:48). Thus La. 1:14; 3:27 accepts it.

ע1 עד ע1', see D.N. Freedman, "'Mistress for ever"', Biblica 51 (1970) 538. 
and the hearer shudders, for the first nine times this word occurs in the Hebrew Bible, through the Hexateuch, it is on Yahweh's own lips, beginning with Exodus 3:12-14 (cf. e.g., Je. $11: 4$ and all the other fourteen occurrences in JeremiahMalachi). The change comes with the foolish Jephthah, who says 'I will be your head' (Judg. 11:9). Madam Babylon is as frighteningly foolish. Her 'I am' confronts Yahweh's repeated 'I' (e.g., 44:24; 45:3, 5, 6, 7, 8, 18, 19, 21, 22; 46:4, 9).

Given the interlinking parallelism presupposed above, as the two expressions for perpetuity interlink, so in all likelihood do the other two words, as verb and predicate: prosaically put, 'I will be mistress for ever and in perpetuity'. But the effect of separating out the words is to isolate 'I will be' and heighten its significance, and also to juxtapose 'mistress' and 'perpetuity' in the way noted above which hints at an underlining of an implicit claim to the eternity which also characterises God alone (as well as 9:6 [5], cf. 45:17; 57:15).

V. 7b. You did not call these things to mind. You did not think about its outcome. Madam Babylon will be tempted to regard what happens as just a bad dream. ${ }^{42}$ It makes sense to take the expression 'these things' as primarily forward-looking even if taking into account what has preceded (as at 44:21; 46:8). The two cola have parallel meaning, and 'these things' is thus initially explained by 'its outcome' (Torrey 370). For Ms Sion's failure to 'think about its outcome', see 41:22; 46:10; but also Lamentations 1:9. The following verses will unfold what 'these things/its outcome' means.

\section{IV. 'I am, and there is None besides $\mathrm{me}^{\prime}$ (vv. 8-11)}

V. 8a. So now listen to this, delectable, you who sit in confidence, you who say to yourself 'I and I alone am still here'. 'So now' (וערתה) suggests that again 'this' denotes what is about to be said. The prophet speaks like any other prophet announcing doom on Ms Sion; it would be comforting to hear such a prophecy directed

${ }^{42}$ Cf. R. Lack, La symbolique du livre d'Isaïe (AB 59; Rome: Pontifical Biblical Institute, 1973) 105. 
elsewhere. A wise exilic community would no doubt assume that there was a barb for them somewhere, and the barb will come in ch. 48 , but for the moment ועתה has similar resonances to those it has in 43:1.43 A comparable point emerges from the verb 'listen' (שמע), which last occurred in the hiphil at 45:21 when Yahweh asked who had 'informed' anyone of the coming fall of Babylon. In giving Babylon something to listen to which constitutes the very bringing about of that fall, Yahweh is once again satisfying the criteria for recognition as real God. The message of humiliation for Babylon links with the message of deliverance for all peoples. 44

'Delectable' (עדינה) comes only here (ignoring the difficult 2 Sa. 23:8). Related words suggest that the central reference is to good food and its enjoyment, which can be a metaphor for sexual pleasure, for inner delight, and then for rich spiritual provision. None of this usage suggests excessive luxury or licentiousness, to which the context makes no other reference; compare rather the two adjectives in $\mathrm{v} .1 \mathrm{~b}$. The critique resembles that of 32:9-13 rather than that of 3:16-26. It confronts the enjoyment of the good life heedless of the danger one is in. Three times in 32:9-13 women at ease are warned about being בטחות (confident). Here the point is made by combining the 'sit' of vv. 1 and 5 with adverbial לבטח in confidence'. The words can suggest objective security or subjective trust and reliance, whether well-founded or false. Madam Babylon sits full of confidence in the future, a sitting which contrasts with the nightmare reality of the sitting which the prophet has portrayed in vv. 1 and 5. 'Sit' can imply 'sit enthroned', especially where the participle is used ( $c f .10: 13$;

${ }^{43}$ Cf. R.P. Merendino, Der erste und der Letzte (VTS 31; Brill: Leiden, 1981) 492. In Concentricity and Continuity (JSOTS 188; Sheffield: Sheffield Academic Press, 1994) 151-59, R.H. O'Connell treats 47:8-15 independently of $47: 1-7$ as the 'structural axis' of chs. 40-54, without specific addressee, and capable of applying to Sion or to Babylon. This seems to underestimate the significance of the way vv. 8-15 follow directly on vv. 1-7, addressed to Babylon. Though Sion was mentioned in 46:13, there is no indication that she might be addressed here. On the contrary, the context suggests strongly that Babylon is still the addressee.

${ }^{44}$ See Hermisson's comments on the passage. 
$37: 16$; BDB 442b), and this connotation is appropriate here (Darr 146).

Madam Babylon's actual words are individually ones which have become familiar in Isaiah $40-46$, but comparison with earlier passages reveals that each of the three words is used rather differently here in v. 8. Previously ' predicate, 5 was in this absolute form whereas here it has an ending, and עוד here follows that word rather than following ' ('there is not') as every other time in Isaiah 45-46. The threeword clause needs to be interpreted in its own right rather than as a variant of earlier statements. Literally Madam Babylon says 'I and my exclusivity still [am/will be]'.45 The word אפס has a restrictive sense as in Numbers 22:35; 23:13, while עוד has its frequent meaning 'yet'. Rather than constituting a separate statement of a claim to a God-like exclusivity of being, Madam Babylon's statement expresses the confidence to which the previous line refers and which the next line will re-express, and which her helplessness referred to in v. 15 will belie. Lack (105) suggests that the words just discussed are Babylon's own slogan.

In one sense Madam Babylon is not guilty of the assertiveness of the king of Babylon, who fancies himself as a god (14:13-14), and a woman's besetting sin may well be enjoyment of apparent security rather than striving to make a mark and write her name in heaven, but either can be preliminary to downfall. Further, when she utters the words in v. $8 \mathrm{a} \beta$, she is absolutising herself in relation to other human powers rather than in relation to God. Her use of the word ' $\mathrm{I}$ ' does risk divinising herself, for the absolute ' $\mathrm{I}$ ' belongs to Yahweh ( $c f$. Ezk. 28; and see on v. 7a). It is also noteworthy that when the fools speak to themselves God is at least the topic of conversation (Ps. 14:1; cf. 10:11). But Yahweh forebears from making such points. Even on an earthly level, in her

45See JM 93q, 160n, which takes the ending on יפר a first person suffix, following P. Joüon, 'Notes de lexicographie hébraique', Mélanges de la faculté orientale (Université Saint Joseph, Beyrouth) 5 (1911) 405-15 (408-9). Joüon queries the view in GK $90 \mathrm{kl}$ that the ending is an old paragogic (fuller) case ending, which can be attached to the construct. 
understanding of herself in relation to other nations, her confidence is false.

V. $\mathbf{8 b}$. I shall not sit as a widow or experience the loss of children. Mademoiselle Babylon who became Madam Babylon is now Mrs Babylon, Babylon as a wife and mother. The links with Lamentations explain part of the significance of her further statement of her womanly confidence. The laments' first plaint about Ms Sion is that she sits alone-again this verb recurs, now with the connotation of sitting in mourning-and has become like a widow (La. 1:1). The word אלמנה has narrower connotations than English 'widow'; it is used to designate someone who as a consequence of losing her husband is without support and in need of legal protection. Interpreted, it denotes Babylon's conviction that it will never be a vassal state dependent on some super-power. The word thus states in other words the confidence of v. 8a, Mrs Babylon's assumption that she is secure. ${ }^{46}$

The promises of Ms Sion's restoration presuppose that her experience included both widowhood and the loss of her children $(49: 20-21 ; 51: 18-20 ; 54: 4)$. The death of husbands and children will have been part of the literal reality of the fall of Jerusalem (cf. La. 5:3). Here that becomes a metaphor for the experience of the personified city or empire which loses husband (king?) and children (inhabitants). A woman's husband, and after his death her children, are not only her loved ones but her security, her protection, and her provision. 47 Ms Babylon's confidence (v. 8a) lay in the conviction that neither form of bereavement would happen to her; husband and children are the security which v. 8a referred to. Her conviction as she 'sits' in confidence (v. 8a) that she will never 'sit' as a widow has already been undermined, and these words rendered ironic, by the poem's opening line which bade her 'sit' in the dirt; the verb will recur again in v. 13 in a cutting

${ }^{46} \mathrm{Cf}$. C. Cohen, 'The "widowed" city', JANES 5 (1973) 75-81 (78-79).

${ }^{47} \mathrm{Cf}$. Is. 3:25-4:1; and on the loss of (grown-up) children, $2 \mathrm{Sa} .14: 5-7 ; 1 \mathrm{Ki}$. 17:20. The fact that Hebrew has a special verb, two related adjectives (here (שכול), and three related nouns for the loss of one's children by bereavement perhaps reflects the significance of this experience. 
observation about a burning that will be no comfortable fire to 'sit' before.

V. 9aba. But the two of these will come to you in a moment, in one day. Loss of children and widowhood in fullness are coming upon you. Ms Babylon's confidence will be shown to be false, and she will come to share Ms Sion's experience. She will lose her empire and become another empire's vassal and dependent.

Vv. $9 \mathrm{~b} \beta \gamma-10 \mathrm{a \alpha}$. In the midst of the multiplying of your chants and the great abounding of your charms you were confident in your

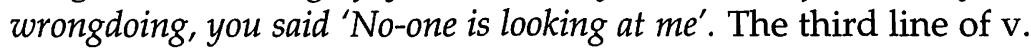
9 introduces the intellectual, political, and spiritual resources which underlay Ms Babylon's sense of security. 'Chants' (כשך) is an adaptation of an Akkadian word for the prayers designed to cause or protect from calamity, a pejorative term even in Akkadian rather like English 'witchcraft' (see G. André, TWAT on כשט). The prophet thus dismisses as witchcraft what the Babylonians would view as prayer designed to counter witchcraft. 'Charms' (דבר) are formulae which 'bind' people (the verb חבר means 'join'), whose words were accompanied by symbolic actions in the form of the tying of knots in rope. The construction hints at a causal as well as a temporal relationship between the two lines: it was because of the multiplying/abounding that Ms Babylon was so confident. The two lines then form less a footnote to v. 9aba than an introduction to v. $10 \mathrm{a} \beta \mathrm{b} .48$ 'The author plays upon yet another commonplace with women, for they were especially, though not exclusively, associated with sorcery and witchcraft in Israel's ancient Near Eastern world'. ${ }^{49}$

RSV has 'you felt secure in your wickedness' but it is doubtful whether בטח ב, which regularly means 'trust in', can be reduced to denoting the circumstances of trust rather than the grounds of trust. The verb presumably keeps the nuance of

${ }^{48}$ See Hermisson's comments on the passage.

${ }^{49}$ Darr, Isaiah's Vision, 174, referring to S. Rollin, 'Women and witchcraft in ancient Assyria', in A. Cameron and A. Kuhrt (eds.), Images of Women in Antiquity (London: Routledge, 1993) 34-45. 
the noun בטח in v. 8 and Ms Babylon is pictured as (?subconsciously) trusting in her wrongdoing as Judah once had $(30: 12 ; c f .28: 15 ;$ Je. $7: 4,8) .50$ So Ms Babylon expresses the conviction that in her wrongdoing she remains unseen and that her wisdom protects her from its consequences. Unfortunately v. 3 has anticipatorily undermined this statement, as the references to sitting in vv. 1 and 5 anticipatorily undermined that in v. 8.51

V. 10aßb. Your wisdom, your knowledge, it was this turned you.52 And you said to yourself 'I and I alone am still here'. Miscall (115) sees in these verses a virtual précis of chs. 28-32 with their treatment of false trust, hiddenness, wisdom, and disaster. Further, from an Israelite perspective it would be impossible for real wisdom and knowledge to co-exist with an indifference to rightness (see, e.g., Dt. 16:19; Pr. 9:9) and a despising of the elder (see Ezk. 27:8-9; cf. H.P. Müller, TWAT on חכח, § III.1).

Admittedly the polemic of Isaiah 28-32 focused on the more empirical/rational wisdom, represented within the Hebrew Bible especially in Proverbs. Verse $9 b \beta$ has already made clear that Isaiah $47^{\prime}$ 's polemic presupposes rather the 'mantic' wisdom of the Babylonian diviners and exorcists which is also prominent in Daniel, that expressed in her chants and charms which were also a foundation of her diplomacy, and more broadly in her famous astrology ( $c f$. v. 13). Such wisdom and knowledge stand in sad contrast to the wisdom and knowledge which truly shape events: see 44:25-26. Yet

50For 'confident in your wrongdoing' (ברעתם), 1QIsa has 'confident in your knowledge' (בדעתך)—the difference is only a tittle. Verbally this fits well with the previous line, and with the next, but elsewhere in ch. 47 and other chapters the prophet views Babylon's wisdom not as sinful but as pathetic. It does not deserve dignifying by the word 'wrongdoing', which needs to be reserved for action such as that in v. $6 \mathrm{~b}$. It would be a shame to remove from v. 10 allusion to that, and the second colon fits such an allusion in the first (cf. Ps. 94:7).

${ }^{51}$ Franke, Isaiah 46, 47, and 48, 148.

52The verb is a polel form of a rare alternative to the hiphil (cf. Je. 50:60. In principle the polel could have any of the meanings of the hiphil; 'turn back' in the sense of 'defeat' seems most likely (cf. 14:27; 44:25; and

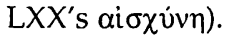


again the chapters tighten the screw of specificity as they unfold: here for the first time they explicitly bring together Babylon/Chaldea and wisdom/divination. As in 44:25-26, however, and in the polemic against images, Isaiah 3:3 would suggest that the prophet's concern regarding mantic wisdom is to attack practices within or temptations for Jacob-Israel itself.

The repetition in v. 10b from v. 8 underlines the fact that it was her intellectual, religious, and political resources that encouraged Ms Babylon's false confidence and thus her fall. She thought she could control her life, her destiny, and her future, but had to find that she could not.

V. 11. Trouble will come upon you of which you will not know the counter charm. Disaster will fall upon you which you will not be able to counter. Desolation will come upon you suddenly which you will not know about. Here the purpose of the chants and charms is explicit. When the diviners' wisdom had revealed what events were likely to take place, the task of the charmers was to ward off attacks, by rites involving symbolic acts such as the destruction of figurines representing enemies and by accompanying prayers.

The verse comprises three parallel lines. Each begins with a verb prefixed by 1 and followed by 'upon you' (עליך): Grimm/Dittert (2:290) call the preposition hostile-aggressive. Three nouns describe the calamity that is destined to come/fall. They combine alliteration with increasing bleakness: trouble, disaster, destruction (שואה,הוה, רעה). Three parallel asyndetic subordinate clauses beginning with לא (not) complete each line. In the first, the verb 'know' involves some irony, underlined by the verb's repetition in the third line, for Ms Babylon thought that her knowledge was one of her strengths (see v. 10); it will transpire that on the contrary she does not know enough. In the second line's clause, the verb is the notoriously controversial כפר (piel); in some way it may be significant that the Akkadian equivalent kupparu refers to the work of a 'chanter', though in connection with purification rites (B. Lang, TWAT on כפר, לא תרע, which in isolation might idiomatically signify 'without your knowing'; but in context the parallelism suggests '[which] 
you do not know'. The knowing will then refer not to previous experience but to the capacity to cope with the event. Perhaps the line-by-line parallelism invites us to understand '...its counter charm/its countering'. Rhetorically the sudden ending to the line mirrors its message in a manner complementary to the unexpected addition of 'suddenly', and thus these relative clauses also heighten to a climax.

\section{You have Wasted so much Energy on so-called Knowledge (vv. 12-15)}

V. 12. Do stand in your charms and in the multiplying of your chants, those in which you have laboured from your youth. Perhaps you may be able to succeed. Perhaps you may terrify. Ms Babylon has three times been told to sit in humiliation and silence. The irony of the challenge now to 'stand' is underlined by the enclitic particle $\mathrm{NI}$ : 'in the light of the uselessness of your wisdom, please do stand upright, firm, and confident in it'. Verse $12 \mathrm{~b}$ takes further the ironic encouragement to see whether Ms Babylon can cope with the future on the basis of her religious, political, scientific, and intellectual resources and the terrifying potential of demons and omens. ${ }^{53}$

V. 13. You are collapsing in the midst of the multiplying of your plans. They must stand now and deliver you, the ones who observe the heavens, those who gaze at the stars, who make known for each month some things which would come upon you. The verb נלאת usually means 'you are weary [with]', but with this meaning the verb is followed by $>$ rather than $\beth$, and in any case that meaning does not fit well in the context. Rather the verb refers to a wearying and collapse which Ms Babylon is about to experience (instantaneous qatal) in the midst of her continuing to plan for her future on the assumption that those spiritual, intellectual, political, and scientific resources will serve her adequately ( $c f$. v. 9b, and the use of the related noun נלאת in Ex. 18:8; 20:14; La. $3: 5 ; \mathrm{Ne} .9: 32$ ). This is the moment when these resources have to

53See Hermisson's comments on the passage. 
prove themselves, but Ms Babylon finds herself at the end of her resources. The moment of her collapse is the moment when her intellectual and religious experts have to stand up and be counted, stand up firm, upright, and confident in their expertise, and demonstrate their ability to deliver. Like wisdom and knowledge, in the present context 'plans' suggests involvement in mantic arts, the Babylonian sages' attempts to determine and control the future by means of their expertise in astrology. But the prophet has already made clear that the only plans which are actually effective are the plan of Yahweh and the plans of Yahweh's aides $(44: 26 ; 46: 10)$.

V. 14. There, they are like stubble. Fire is burning them. They cannot rescue their own selves from the power of the blaze. It is not coal for warming, flame to sit before. The prophet returns to a favourite image for destruction. The experience of Ms Sion will again become the experience of Ms Babylon (La. 1:7, 13; 2:3, 4; 4:11). The point of the advisers' profession was to enable the community to avoid disaster, but far from rescuing Babylon, they cannot even rescue their own selves from this blaze. The verse closes with a bitingly ironic homely scene which extensively recalls the image-making portrayal of 44:15-20. The advisers with all their wisdom and knowledge are as useless as the images and as stupid as their makers and devotees, and will share the fate of both. The point is perhaps made the more strongly through there being no explicit reference to the gods and their images in ch. 47: the pressure is all on the human beings who represent them or rely on them. If they cannot escape the fire, no-one can.

V. 15. For you, such are those with whom you have laboured, your charmers from your youth. They are wandering each of them their own way. There is no-one to deliver you. The point of the previous description of the advisers' helplessness was indeed to underline the helplessness of one who was relying on them, Ms Babylon herself who continues to be the addressee. The helpless wandering with which the portrait closes recalls the opening of ch. 46, as does the specific reference to there being no-one to deliver ( $c f .46: 2,4$; also 45:21). Jacob-Israel can 
overhear the echo of a reminder that they do have a deliverer. There is hardly need to ask what the experts are wandering off to try to do (save themselves? find help?). They are wandering about in shocked helplessness, unable to focus on such possibilities, in the same state of confused bewilderment and terror as everyone else.

\section{Conclusion}

If there is to be an exaltation of Ms Sion it apparently has to be preceded by the humiliation of Ms Babylon. Yet if 'Isaiah 47 exploits the conventional personification of cities as females to describe Babylon's demise in terms of tragedies and afflictions endured by women' (Darr 174), it does so selectively, and the empire's sin is described that way too. There is no rejoicing in vengeance or violence and no reference to Ms Babylon's being stained, as by menstruation, or raped (see the comments on $\mathrm{v}$. 3). 'Remarkably, Queen Babylon's sexual integrity is never impugned.'54 There is no allusion to the woman's attractiveness, whether actual, pretended, misused, or spoilt; בתולה Gordon and Washington (319) suggest that the word implies sexually desirable and available, the object of male fantasy, but they point to no concrete evidence (see the comments on v. 1).

In Isaiah 47 any preoccupation with violence and with female sexuality has disappeared. The chapter does focus on Ms Babylon as a woman of power, and the passage may become instructive as a piece of critique of power even/ especially when exercised by a 'woman'. If a woman's voice can be heard here (Ms Sion's own voice?), interpreters are being given the opportunity to listen into a conversation between two sisters-or rather, to the rebuke of one sister to another who is accused of having given unwomanly priority to power and resources over compassion (see v. 6); she has been too much like a man. Perhaps the embarrassment which exegetes have sometimes felt at the poem is but that of slightly conscientised

54J. Galambush, Jerusalem in the Book of Ezekiel (SBLDS 130; Atlanta: Scholars, 1992) 43. 
male interpreters who nevertheless write from a position of privilege and identification with the status quo and who are at best ambivalent about social change, the kind of interpreters who feel uneasy with the tone of Revelation. 55 The charge with which one sister confronts another is that she has given up her womanliness and will suffer a woman's fate; it is the chapter's fundamental irony.

${ }^{55} \mathrm{Cf}$. A. Yarbro Collins, 'Vilification and self-definition in the Book of Revelation', HTR 79 (1986) 308-20 (309). 